\title{
Pircinque: new strawberry cultivar for Brazilian producers
}

\author{
Antonio Felippe Fagherazzi ${ }^{1} \mathbb{D}$; Fernanda Grimaldi ${ }^{1} \mathbb{D}$; Aike Anneliese Kretzschmar1 ${ }^{1}$; Leo Rufato ${ }^{1} \mathbb{D}$; \\ Marllon Fernando S dos Santos ${ }^{1} \mathbb{D}$; Paolo Sbrighi ${ }^{2} \mathbb{D}$; Pierluigi Lucchi ${ }^{2} \mathbb{D}$; Gianluca Baruzzi ${ }^{2} \mathbb{D}$; Walther \\ Faedi ${ }^{2} \mathbb{D}$
}

${ }^{1}$ Universidade do Estado de Santa Catarina(CAV-UDESC), Lages-SC, Brasil; antonio.fagherazzi@gmail.com; fernandagrimaldi@outlook. com; aike.kretzschmar@udesc.br; leo.rufato@udesc.br; marllon.soares@outlook.com; ${ }^{2}$ Consiglio per la Ricerca in Agricoltura e 1'Analisi dell'Economia Agraria - Centro di Olivicoltura, Frutticoltura e Agrumicoltura (CREA-OFA-FRF), Forlì, Via La Canapona 1bis, 47122 Forlì (FC), Itália; gianluca.baruzzi@crea.gov.it

\begin{abstract}
The strawberry cultivar 'Pircinque' was developed by the breeding program of Consiglio per la Ricerca in Agricoltura e l'Analisi dell'Economia Agraria - Centro di Olivicoltura, Frutticoltura e Agrumicoltura (CREA-OFA-FRF), an Italian research entity, and introduced in Brazil in 2013 by the Centro de Ciências Agroveterinárias da Universidade do Estado de Santa Catarina (CAVUDESC). In the breeding program in which it originated, 'Pircinque' was selected for plant rusticity and resistance to soil pathogens. It can be cultivated where soil sterilization techniques are not used. In Brazil, the cultivation of 'Pircinque' has shown to be promising in the major strawberry producing regions. The main characteristics that allowed the development of this cultivar among the growers were plant vigor, productivity, rusticity, flavor, pulp firmness, crispness, sweetness and fruit color. When grown with excessive nitrogen fertilization fruit sensitivity to Botrytis cinerea fungal attack has been found, and a high vegetative plant growth. Due to fruits peculiarity, many growers make differentiated sales, adding value to quality product. Also, due to the high post-harvest period, many growers allocate part of the production to more distant locations. These characteristics are determinant for the cultivar Pircinque be distinguishable from other strawberry cultivars already marketed in Brazil. The cultivar was registered at the Ministério da Agricultura, Pecuária e Abastecimento (MAPA) in 2016, and the commercialization of plants started in 2017 with five nurseries accredited to produce and market 'Pircinque' plants throughout Brazil.
\end{abstract}

Keywords: Fragaria $x$ ananassa, breeding, cultivars introduction, genetic adaptability.

\section{RESUMO}

Pircinque: nova cultivar de morangueiro para os produtores brasileiros

A cultivar de morangueiro 'Pircinque' foi desenvolvida pelo programa de melhoramento genético do Consiglio per la Ricerca in Agricoltura e l'Analisi dell'Economia Agraria - Centro di Olivicoltura, Frutticoltura e Agrumicoltura (CREA-OFA-FRF) da Itália, e introduzida no Brasil em 2013 pelo Centro de Ciências Agroveterinárias da Universidade do Estado de Santa Catarina (CAVUDESC). No programa de melhoramento em que foi originária, 'Pircinque' foi selecionada pela rusticidade da planta e resistência aos patógenos de solo, sendo indicada para o cultivo, em terrenos onde não são realizadas técnicas de esterilização do solo. No Brasil, o cultivo de 'Pircinque' tem se mostrado promissor nas principais regiões produtoras de morango. As principais características que permitiram o desenvolvimento desta cultivar junto aos produtores foram vigor da planta, produtividade, rusticidade da planta, sabor, firmeza de polpa, crocância, doçura e coloração das frutas. Quando cultivada com excesso de adubação nitrogenada, tem-se verificado sensibilidade das frutas ao ataque do fungo Botrytis cinerea, e a um elevado crescimento vegetativo da planta. Devido à peculiaridade das frutas, muitos produtores realizam vendas diferenciadas, agregando valor ao produto de qualidade. Também, pelo elevado período de pós-colheita, muitos produtores destinam parte da produção para locais mais distantes. Estas características são determinantes para que a cultivar 'Pircinque' seja distinguível das demais cultivares de morangueiro já comercializadas no Brasil. A mesma foi registrada junto ao Ministério da Agricultura, Pecuária e Abastecimento (MAPA) em 2016 e a comercialização das mudas de 'Pircinque' teve início no ano de 2017 com cinco viveiros credenciados para produzir e comercializar as mudas em todo território brasileiro.

Palavras-chave: Fragaria $x$ ananassa, melhoramento, introdução de cultivares, adaptabilidade genética.

\section{Received on February 4, 2021; accepted on October 1, 2021}

$\mathrm{C}$ urrently, fresh fruit Brazilian production is estimated at an annual volume of 45 million tons on a cultivated area of about 2.7 million hectares, making Brazil the third largest world fruit producer (ABF, 2017). Of the total volume produced with fruit trees, only $0.4 \%$ come from the species that make up the small fruits group (blackberry, blueberry, raspberry and strawberry) (Fagherazzi et al., 2017b). Of these, strawberry is the main species under cultivation in Brazil, with approximately 4,500 hectares and an annual production of around 165,440 
tons (FAOSTAT, 2020).

The main Brazilian strawberry producing poles are located between the $20^{\circ}$ and $32^{\circ}$ south latitude parallels (Fagherazzi et al., 2014). Due to the country high edaphoclimatic diversity, the small cultivars number available to producers becomes one of the main difficulties for the strawberry trees' development (Oliveira \& Scivittaro, 2011). Therefore, it is important to encourage national genetic improvement programs, as well as the introduction of new strawberry cultivars developed in other countries (Oliveira \& Scivittaro, 2011). In the last seven years, ten new cultivars were registered on the National Cultivar Registry (NCR) of the Agriculture, Livestock and Supply Ministry, (ALSM), namely: 'Cristal' (2010), 'Flórida Fortuna' (2011), 'Sabrina ' (2012), 'Benicia' (2013), 'Florida Elyana' (2013), 'Mojave' (2013), 'Sweet Ann' (2013) and 'PRA Estiva', 'Jonica' and 'Pircinque' in 2016 (MAP, 2017).

In Brazil, strawberry production is concentrated in the Albion, San Andreas and Camarosa cultivars, which together represent approximately $60 \%$ of fruit crops. Due to the large geographic area where strawberry is cultivated, and due to the different specific conditions of each location, there are few cultivars used by producers (Fagherazzi et al., 2017b). There is a lack of cultivars adapted for the different cultivation locations and for the various cultural techniques that are used by the producers, as all the cultivars used for fruit production come mainly from United States genetic improvement programs. So there are no cultivars developed especially for the Brazilian climate and soil conditions (Carpenedo et al., 2016).

Due to the limited availability of strawberry cultivars with Brazilian producers, Santa Catarina State University, through the Agricultural Sciences Center (ASC-UDESC) signed an "Agreement for the experimentation and dissemination of Italian strawberry genetic material in Brazil". This cooperation agreement between UDESC and Consiglio per la Ricerca in Agricoltura e l'Analisi dell'Economia Agraria - Centro di Olivicoltura,
Frutticoltura e Agrumicoltura (CREAOFA-FRF) began in 2012 and aims to introduce Italian strawberry genotypes in Brazil. The CREA-OFA-FRF genetic improvement program began in 1960 and since then more than 30 strawberry cultivars have been created. Currently, CREA-OFA-FRF coordinates eight genetic improvement programs located in the main Italy strawberry producing regions (Baruzzi et al., 2017).

Criteria to define, choose and/or indicate a new cultivar are numerous, however the main aspects sought by strawberry genetic improvement programs for plant characteristics are productivity, vigor, fruiting habit, precocity, production seasonality, cold resistance, high temperatures tolerance and diseases and pests' resistance (Castro, 2004). For fruits, the characteristics flavor, aroma, crunchiness, size, uniformity, shape, pulp firmness and epidermis color, brightness, soluble solids content, acidity and resistance to rot are desired (Castro, 2004). Strawberries qualitative characteristics are not only based on uniformity, size and color, but also on the complex balance between sweetness, aroma and texture (Jouquand et al., 2008).

Given the above, the objective of this research was to validate in Brazil the use of the Italian strawberry cultivar 'Pircinque', making it a new cultivation option for strawberry producers.

\section{VARIETAL HISTORY}

Origin: 'Pircinque' cultivar was created in Italy by CREA-OFA-FRF through a public-private genetic improvement program in partnership with Piraccini Secondo Ltda Company. The objective of this genetic improvement program is the search for strawberry cultivars widely adapted to the edaphoclimatic conditions of Metaponto, a locality established in the Basilicata Region, southern Italy (Baruzzi et al., 2017).

'Pircinque' (selection PIR 04.228.05) was originated from a controlled crossing between the cultivars Nora x Ventana, carried out in 2004, in the city of Cesena (FC). In the first plants generation obtained by crossing, in 2006 , in the city of Scanzano Jonico, the PIR genotype 04.228.05 was selected in the genetic field of 'seedlings' due to the characteristics of growth habit, plant rusticity, large, uniform and conical shape fruits, and the plant sensitivity to the short photoperiod (Faedi et al., 2014).

Creators: Dr. Walther Faedi, Dr. Gianluca Baruzzi (Faedi et al., 2014).

Rights ownership: CREA-OFAFRF and Piraccini Secondo Ltda.

Commercial management and intellectual property: In the European Union under the responsibility of CREA-OFA-FRF and in Brazil by UDESC.

Introduction: in 2013 UDESC introduced in Brazil eleven strawberry genotypes from different genetic improvement programs of CREAOFA-FRF, including the cultivar 'Pircinque', which at that time was a newly disseminated cultivar in Italy.

Seedling propagation and sale: in the European Union, the nurseries licensed by CREA-OFA-FRF are: Viveiro COVIRO, APOFRUIT Itália and Piraccini Secondo Ltda. In Brazil, the nurseries licensed by UDESC are: Viveiro Fragaria Brasil, Viveiro Pasa, Viveiro Amauri Donizetti De Moraes, Viveiro Airton Donizetti Binoti and Viveiro de mudas Irmãos Baptistella Ltda.

\section{VARIETAL DESCRIPTORS}

Plant: 'short day' cultivar, with semi-erect growth habit and high leaf density, vigor and hardiness (Figure 1A).

Leaves: large, light green color, low or almost absent internerval bulging, medium brightness and no variegation (Figure 1B).

Central leaflet: same length in relation to width, base shape classified as acute, crenated margin and flat shape in cross section.

Petiole: long length and with hair in the perpendicular position.

Inflorescence: with small flowers 
amount.

Flower: large diameter, larger calyx in relation to the corolla and with stamens presence.

Fruit: pulp and heart color classified as light red (Figure 1C), firm fruit, very large, uniform conical shape, much longer than wide, uniform medium red color, strong shine (Figure 1D), achenes positioned below from the surface level, prominent insertion of the chalice, sepals upwards (direction opposite to the fruit), equal diameter of the chalice and median adhesion to the chalice.

\section{AGRONOMIC DESCRIPTORS}

Planting: preferably carried out under mild temperature conditions $\left(<7^{\circ} \mathrm{C}\right)$. It is recommended that planting starts in March for the southern region. For places with high temperatures $\left(>25^{\circ} \mathrm{C}\right)$, in plantings to be carried out with bare-root fresh plants containing leaves, it is essential to use sprinkler, micro-spray, or mist irrigation systems,

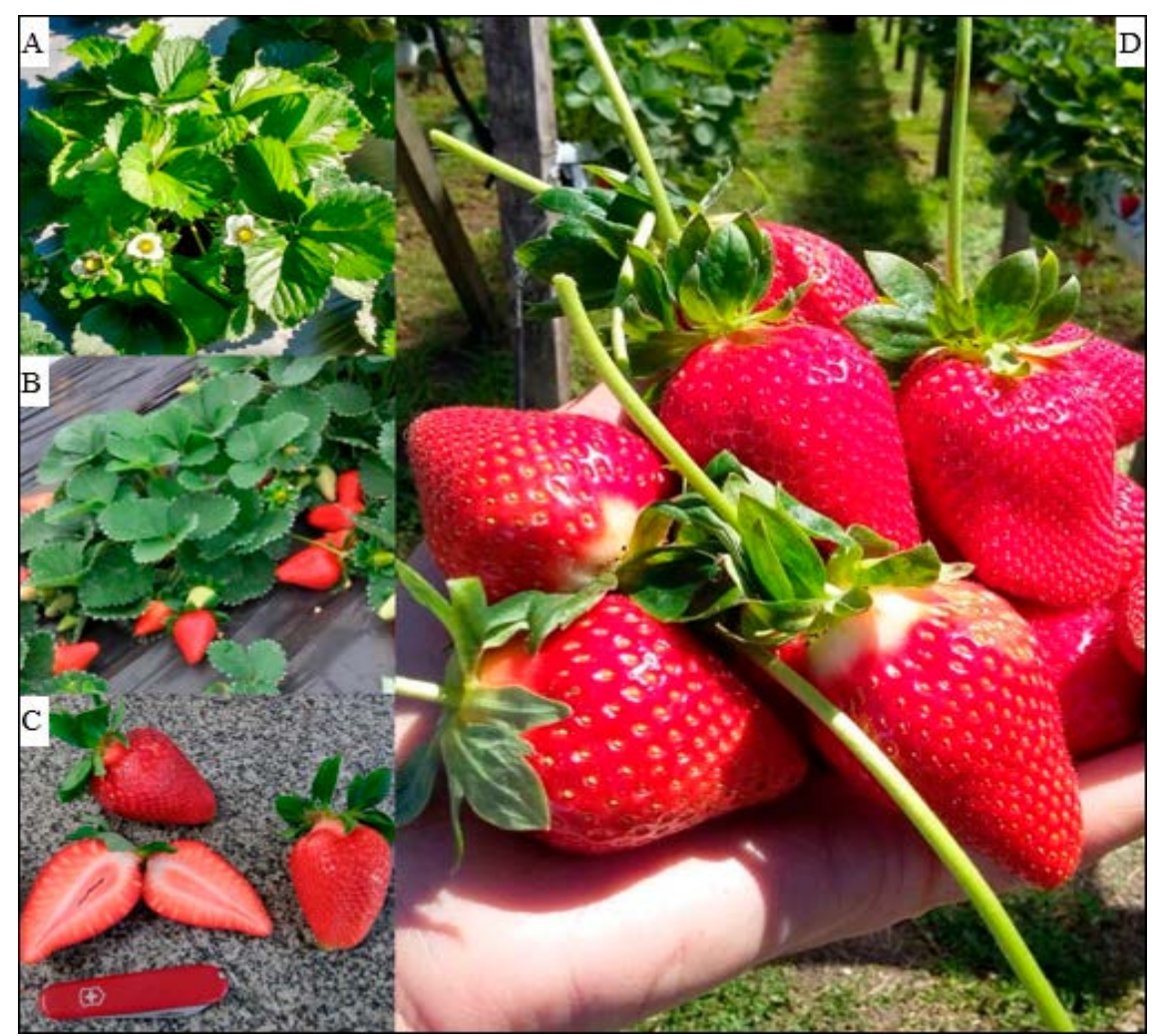

Figure 1. Characteristics of plants (A and B) and fruits (C and D) of strawberry cultivar 'Pircinque'. Lages, CAV-UDESC, 2018. so that the leaves and plants are not exposed to dehydration. For the best productive performance, it is advisable that the planting window be completed by the first half of May, allowing the stages of induction and floral differentiation to be uninterrupted by adverse weather conditions, such as the lack of winter cold (Manakasem \& Goodwin, 2001). 'Pircinque' cultivar can be grown in soil and/or in different off-ground cultivation systems.

Planting density: in the soil it can vary from 40 to 60 thousand plants per hectare, different spacing between plants and rows being adopted: $30 \times 30 \mathrm{~cm}$; $30 \times 35 \mathrm{~cm} ; 30 \times 40 \mathrm{~cm} ; 30 \times 50 \mathrm{~cm}$; $35 \times 40 \mathrm{~cm} ; 40 \times 40 \mathrm{~cm}$. For off-ground cultivation, it is advisable to use a density of five to seven plants per linear meter (13 to $20 \mathrm{~cm}$ spacing between plants). Due to the characteristics of the cultivar, it is advisable to adopt spacing that provides lower plant densities per hectare or per linear meter.

Nutrition: due to the rusticity and plant high vigor, it is recommended to reduce the use of nitrogen fertilizers and avoid the use of organic compounds rich in nitrogen in 'base fertilization'. Excessive vigor in plants can directly favor the increase in leaf area and cell turgor, creating a favorable condition for the entry of diseases, especially gray mold caused by the fungus Botrytis cinerea, and for decreasing the firmness of fruit pulp. Studies also report that excessive doses of nitrogen can increase the acidity of strawberry fruits, decrease fruit production and the crown diameter of plants (Andriolo et al., 2011). Better control of nitrogen levels can positively influence plant development without intensifying the stimulus for vegetative growth (Otto et $a l ., 2009)$. On the other hand, the plants of the 'Pircinque' cultivar demonstrate to be more demanding for the nutrients calcium, phosphorus, magnesium and micronutrients.

Production: can start from 45 days after the planting date in places with 'hot' climate, and around 120 days after planting in places with 'cold' climate, with severe winters.

Harvest: due to the qualitative characteristics of the fruit, especially the high pulp firmness and uniform red color, it is advisable to harvest 'Pircinque' fruits when they reach almost all of the surface of the epidermis with an intense red color.

Post-harvest: due to the high pulp firmness characteristic of the cultivar, the fruits have a long shelf-life and the uniform red color is maintained during cold storage (Faedi et al., 2014). However, the pulp firmness and post-harvest characteristics may be influenced by the environment and cultural treatments, especially irrigation, nutrition and fruit harvesting point (Santos, 1999).

Commercialization: due to the qualitative characteristics of the fruits, which meet the main demands of producers and consumers, their commercialization can be carried out in a differentiated way, adding value and building consumer loyalty.

Diseases: as it is a rustic cultivar with an expansive root system, the plant's tolerance to soil pathogens and to the attack of mites is verified, making it a cultivation possibility for 
organic producers. On the other hand, it is susceptible to Botrytis cinerea (grey mold) and Sphaerotheca macularis (powdery mildew) (Faedi et al., 2014).

\section{AGRONOMIC PERFORMANCE}

Through cultivar comparison studies, it is possible to judge and indicate which cultivars are adapted to specific locations as a function of edaphoclimatic conditions and cultivation techniques (Baruzzi et al., 2017).

To validate the performance of 'Pircinque' cultivar in Brazil, the present study was conducted in two cultivation cycles (2014/2015 and 2015/2016) in Santa Catarina "Planalto Sul" region, where the 'Pircinque' cultivar was subjected to two different studies: a) comparison test with the cultivars most used by Brazilian producers (Camarosa and Albion); and b) to evaluate the response of 'Pircinque' cultivated with two different types of seedlings (bareroot fresh plants). For both studies, the seedlings were produced by a national

Table 1. Mean values of number of fruits (NF), fruit weight (FW), total production (TP), soluble solids (SS) and pulp firmness (PF) of the cultivars evaluated during two growing cycles. Lages, CAV-UDESC, 2018.

\begin{tabular}{|c|c|c|c|c|c|c|}
\hline Cultivar & Planting & $\begin{array}{c}\text { NF } \\
\left.\text { (un plant }{ }^{-1}\right)\end{array}$ & $\begin{array}{c}\text { FW } \\
\left(\text { g fruit }^{-1}\right)\end{array}$ & $\begin{array}{c}\text { TP } \\
\left.\text { (g plant }^{-1}\right)\end{array}$ & $\begin{array}{c}\text { SS } \\
\left({ }^{(} \text {Brix }\right)\end{array}$ & $\begin{array}{l}\text { PF } \\
\text { (g) }\end{array}$ \\
\hline \multicolumn{7}{|c|}{ Cycle 2014/2015 } \\
\hline Albion & & $45.0 \mathrm{ab}$ & $19.6 \mathrm{~b}$ & $748.6^{\mathrm{ns}}$ & $7,2 \mathrm{~b}$ & $310 \mathrm{~b}$ \\
\hline Camarosa & $08 / 04 / 2014$ & $48.3 \mathrm{a}$ & $18.9 \mathrm{~b}$ & 730.5 & $7,4 \mathrm{~b}$ & $290 \mathrm{~b}$ \\
\hline Pircinque & & $41.0 \mathrm{~b}$ & $22.2 \mathrm{a}$ & 744.3 & $8,5 \mathrm{a}$ & $350 \mathrm{a}$ \\
\hline Average & - & 44.7 & 20.2 & 741.1 & 7,7 & 317 \\
\hline DMS $(0,05)$ & - & 5.0 & 2.5 & 231.2 & 0,7 & 25 \\
\hline $\mathrm{CV}(\%)$ & - & 4.5 & 4.9 & 12.4 & 3.7 & 3.2 \\
\hline \multicolumn{7}{|c|}{ Cycle 2015/2016 } \\
\hline Albion & & $37.6 \mathrm{c}$ & $18.6^{\mathrm{ns}}$ & $674.3 \mathrm{~b}$ & $6.5 \mathrm{~b}$ & $324 \mathrm{ab}$ \\
\hline Camarosa & $10 / 04 / 2015$ & $65.0 \mathrm{a}$ & 17.2 & $959.6 \mathrm{a}$ & $5.7 \mathrm{c}$ & $309 \mathrm{~b}$ \\
\hline Pircinque & & $49.6 \mathrm{~b}$ & 19.2 & $838.3 \mathrm{a}$ & $7.8 \mathrm{a}$ & $357 \mathrm{a}$ \\
\hline Average & - & 50.7 & 18.4 & 824.1 & 6.7 & 330 \\
\hline DMS (0.05) & - & 7.3 & 2.5 & 137.3 & 0.7 & 35 \\
\hline CV $(\%)$ & - & 5.0 & 4.8 & 5.7 & 4.0 & 3.7 \\
\hline
\end{tabular}

*Means followed by the same letter in the column do not differ statistically from each other by the $5 \%$ level Tukey test probability of error; DMS= minimum significant difference. ${ }^{\mathrm{ns}}$ not significant.

nursery, which had the National Register of Seeds and Seedlings (RENASEM). The practices adopted in the research were conventional soil cultivation, in a cover system with low tunnels. The experimental design used was randomized blocks, with four plots containing 11 useful plants.

We observed in 'Pircinque' a smaller number of fruits emitted per plant, differing from 'Camarosa', the cultivar that emitted more fruits in the two evaluation cycles (Table 1). In current genetic improvement programs, an important characteristic is the size of the fruits. It is preferable for a cultivar to emit less fruits, as long as they are larger. Thus, a producer would have less demand in labor to carry out the harvests. For the characteristic of fruits fresh mass, we verified in the cultivar 'Pircinque' fruits of larger size during the $2014 / 2015$ cycle, while in the 2015/2016 cycle similar performance was observed in three cultivars.

For total production variable, the cultivar 'Pircinque' did not differ from the cultivars 'Albion' and 'Camarosa' during the first evaluation cycle; in the second cycle, it showed $25 \%$ higher

Horticultura Brasileira 39 (4) October - December, 2021 productivity compared to 'Albion', however, not differing from 'Camarosa'. In terms of soluble solids, the 'Pircinque' cultivar performs better than the other cultivars for both agricultural cycles. We also observed in 'Pircinque' greater fruit pulp firmness, superior or similar to 'Albion' and superior to 'Camarosa'. 'Pircinque' is characterized by the balance of the main desired characteristics, productivity associated with the quality of the fruit.

In the second study with 'Pircinque', comparing the use of plug plant and bare-root fresh plants, no significant difference was observed in the main characteristics evaluated during the two agricultural cycles (Table 2). Thus, for the "Planalto Sul" Santa Catarina region, in 'Pircinque' cultivation the type of seedling used by the producer is independent, however, he can opt for the seedling with a lower acquisition cost.

Previous studies have already compared 'Pircinque' cultivar behavior in other countries. In a study comparing six cultivation sites (four in the Huelva Region, Spain; and two in the Basilicata Region, Italy), in comparison with 11 other strawberry cultivars (Amiga, Antilla, Benicia, Camarosa, Florida Fortuna, Fuentepina, Mojave, Primoris, San Andreas, Sabrosa ${ }^{\circledR}$ Candonga and Splendor), 'Pircinque' was characterized as a vigorous cultivar, with high productivity, with large, very sweet and firm fruits, standing out together with the cultivars Primoris, Camarosa and Sabrosa ${ }^{\circledR}$ Candonga (Medina et al., 2014).

In another research carried out in Southern Italy, the 'Pircinque' cultivar obtained the highest total production $\left(809 \mathrm{~g} \mathrm{plant}^{-1}\right)$, fresh fruit mass (30.6 $\left.\mathrm{g} \mathrm{fruit}^{-1}\right)$, texture $(575 \mathrm{~g})$, sucrose $(2.3$ $\mathrm{g}) / 100 \mathrm{~g})$, fructose $(2.2 \mathrm{~g} / 100 \mathrm{~g})$ and glucose $(2.5 \mathrm{~g} / 100 \mathrm{~g})$ compared to 'Camarosa' and 'Sabrosa-Candonga ${ }^{\circledR}$ ' cultivars (Faedi et al., 2014). In Brazil, a study comparing six strawberry cultivars (Camarosa, Oso Grande, Strawberry Festival, Albion, Jonica and Pircinque) under the conditions of the "Planalto Sul Catarinense" found in the 'Pircinque' cultivar the highest correlations between 'pulp firmness' ( $g$ fruit $\left.^{-1}\right) \times$ total production $\left(\mathrm{g} \mathrm{plant}^{-1}\right)^{\prime}$; 
Table 2. Mean values of number of fruits (NF), fruit weight (MF), total production (PT), soluble solids (SS) and pulp firmness (PF) of the strawberry cultivar 'Pircinque' cultivated with different types of plants during two growing cycles. Lages, CAV-UDESC, 2018.

\begin{tabular}{|c|c|c|c|c|c|c|}
\hline Pircinque & Planting & $\begin{array}{c}\text { NF } \\
\left(\text { un plant }{ }^{-1}\right)\end{array}$ & $\begin{array}{c}\text { FW } \\
\left(\text { g fruit }^{-1}\right)\end{array}$ & $\begin{array}{c}\text { TP } \\
\text { g plant }^{-1} \text { ) }\end{array}$ & $\begin{array}{c}\text { SS } \\
\left({ }^{\circ} \text { Brix }\right)\end{array}$ & $\begin{array}{l}\text { PF } \\
\text { (g) }\end{array}$ \\
\hline \multicolumn{7}{|c|}{ Cycle 2014/2015 } \\
\hline Bare root & $08 / 04 / 2014$ & $67.3^{\text {ns }}$ & 19.7 & 826 & 8.7 & 415 \\
\hline Plug Plant & $08 / 04 / 2014$ & 71.6 & 20.2 & 976 & 8.5 & 393 \\
\hline Average & - & 69.5 & 19.9 & 901 & 8.6 & 404 \\
\hline DMS (0.05) & - & 11.1 & 4.2 & 247 & 0.6 & 54 \\
\hline $\mathrm{CV}(\%)$ & - & 7.1 & 9.3 & 12.0 & 3.1 & 5.8 \\
\hline \multicolumn{7}{|c|}{ Cycle 2015/2016 } \\
\hline Bare root & $10 / 04 / 2015$ & $46.5^{\mathrm{ns}}$ & 19.8 & 805 & 8.1 & 437 \\
\hline Plug Plant & $10 / 04 / 2015$ & 49.4 & 19.0 & 878 & 7.8 & 416 \\
\hline Average & - & 47.9 & 19.4 & 841 & 8.0 & 427 \\
\hline DMS (0.05) & - & 23.0 & 2.7 & 83 & 1.3 & 168 \\
\hline CV $(\%)$ & - & 13.6 & 4.0 & 2.8 & 4.8 & 11.2 \\
\hline
\end{tabular}

*Means followed by the same letter in the column do not differ statistically from each other by the $5 \%$ level Tukey test probability of error; DMS= minimum significant difference. ${ }^{\mathrm{ns}}$ not significant.

'soluble solids ( ${ }^{\circ}$ Brix $) \mathrm{x}$ total production $\left(\mathrm{g}\right.$ plant $\left.{ }^{-1}\right)$ ' and between 'soluble solids $\left({ }^{\circ}\right.$ Brix) x pulp firmness $\left(\mathrm{g}\right.$ fruit $\left.{ }^{-1}\right)$ ' (Fagherazzi et al., 2017a).

\section{REGISTRATION, PROTECTION, COMMERCIAL DISSEMINATION AND LICENSING}

CREA-OFA-FRF and Piraccini Secondo Ltda. company, delegated to UDESC the right to register, protect, disseminate and commercially exploit the intellectual property of the 'Pircinque' cultivar for the Brazilian territory. The cultivar has been registered with the National Cultivar Registry (RNC) since 03/23/2016 under number 35355 and with the intellectual property protection certificate number 20180069.

Currently, UDESC has licensed five nurseries to produce and market 'Pircinque' seedlings. They are: Viveiro Fragaria Brasil, Pouso Alegre-MG, phone: (35) 99704 5678; Viveiro Pasa, Farroupilha-RS, phone (54) 99913 2223; Nursery Amauri Donizetti De
Moraes, Socorro-SP, phone (19) 99753 6440; Airton Donizetti Binoti Nursery, Socorro-SP, phone (19) 99148 2994; and Seedling Nursery Irmãos Baptistella Ltda, Itatiba-SP, phone (11) 975472989.

Basic plant and matrices: the basic plants of the 'Pircinque' cultivar are registered with the Agriculture Ministry under registration number SC-0123/2017 and are maintained by the Fruit Growing sector, at the UDESC Agricultural Science Campus. The basic plant is cultivated for the propagation of new plants and for the collection of meristems, which will serve to produce mother plants through in vitro cultivation.

For more information: other information can be requested and/or accessed through the following media:

Correspondence: Centro de Ciências Agroveterinárias da Universidade do Estado de Santa Catarina, CAV-UDESC, Av. Luiz de Camões, 2090, Bairro Conta Dinheiro, 88520-000, Lages-SC.

Phones: +55 (49) 3289 9179, (49) 32899159 and (49) 32899173.

Website: http://www.cav.udesc.br com

\section{ACKNOWLEDGMENTS}

The authors thank the rural producers who contributed to the development of the 'Pircinque' cultivar, and the public and private research and extension entities, CAV-UDESC, UDESC, CREAOFA-FRF, FAPESC, CAPES, CNPq, IFRS, IFSC, UCS, EMBRAPA, MAPA, CENARGEM, EPAGRI, EMATER-RS, EMATER-MG, Nursery Fragaria Brasil, Nursery Pasa, Nursery Amauri Donizetti de Moraes, Nursery Airton Donizetti Binoti, Nursery of seedlings Irmãos Baptistella Ltda., and the company Piraccini Secondo Ltda., for the support, promotion of research, granting of scholarships and in the assistance and execution of the activities carried out.

\section{REFERENCES}

ABF - Anuário Brasileiro de Fruticultura. 2017. Santa Cruz do Sul. 49p.

ANDRIOLO, JL; ERPEN, L; CARDOSO, FL; COCCO, C; CASAGRANDE, GS; JÄNISCH, DI. 2011. Nitrogen levels in the cultivation of strawberries in soilless culture. Horticultura Brasileira 29: 516-519.

BARUZZI, G; BALLINI, L; BARONI, G; BIROLLI, M; CAPRIOLO, G; CARULLO, A; D'ANNA, F; FUNARO, M; LUCCHI, P; MAGNANI, S; MALTONI M; SBRIGHI, P; TURCI, P; FAEDI, W. 2017. Updates on Italian strawberry breeding programs coordinated by CREA-OFA-FRF. Acta Horticulturae, 1156: 179-184.

CARPENEDO, S; ANTUNES, LEC; TREPTOW, RO. 2016. Caracterização sensorial de morangos cultivados na região de Pelotas. Horticultura Brasileira 34: 565-570.

CASTRO, RL. Melhoramento genético do morangueiro: avanços no Brasil. 2004. In: SIMPÓSIO NACIONAL DO MORANGO, 2.; ENCONTRO DE PEQUENAS FRUTAS E FRUTAS NATIVAS DO MERCOSUL, L, Pelotas. Palestras ... Pelotas: Embrapa Clima Temperado, 2004. p.22-36.

FAEDI, W; BARUZZI, G; LUCCHI, P; MAGNANI, S; CARULLO, A; MALTONI, ML; MIGANI, M; SBRIGHI, P. 2014. The new 'Pircinque' strawberry cultivar released under Italy's PIR Project. Acta Horticulturae 1049: 961-966.

FAGHERAZZI, AF; BORTOLINI, AJ; ZANIN, DS; BISOL, L; SANTOS, AM; GRIMALDI, F; KRETZSCHMAR, AA; BARUZZI, G; FAEDI, W; LUCCHI, P; RUFATO, L. 2017a. New strawberry cultivars and breeding activities in Brazil. Acta Horticulturae 1156: 167-170

FAGHERAZZI, AF; COCCO, C; ANTUNES, 
LEC; SOUZA, J; RUFATO, L. 2014. La fragolicoltura brasiliana guarda avanti. Rivista di Frutticoltura e di Ortofloricoltura 75: 20-24.

FAGHERAZZI, AF; KRETZSCHMAR, AA; MACEDO, TA; VIGNOLO, GK; ANTUNES, LEC; KIRSCHBAUM, DS; GIMENEZ, G; ZOPPOLO, R; JOFRÈ, F; RUFATO, L. 2017b. La coltivazione dei piccoli frutti in Sud America: non solo mirtilli. Rivista di Frutticoltura e di Ortofloricoltura 85: 02-05.

FAOSTAT, 2020. Área colhida, rendimento e produção nos principais países produtores de morangueiro. Available $<$ http://www.fao. org/faostat/en/\#data/QC $>$. Accessed June 29, 2021.

JOUQUAND, J; CHANDLER, C; PLOTTO, A;
GOODNER, K. 2008. A sensory and chemical analysis of fresh strawberries over harvest dates and seasons reveals factor that affect eating quality. Journal of the American Society for Horticultural Science 133: 859-867.

MANAKASEM, Y; GOODWIN, PB. 2001. Responses of dayneutral and Junebearing strawberries to temperature and daylength. The Journal of Horticultural Science and Biotechnology 76: 629-635.

MAPA - Ministério da Agricultura pecuária e Abastecimento. 2017, 23 de maio. CultivarWeb, Registro Nacional de Cultivares (RNC). Available http://extranet.agricultura. gov.br/php/snpc/cultivarweb/cultivares registradas.php

MEDINA, JJ; MIRANDA, LD; SORIA, C;
ARANDA, JML; BARUZZI, G; FAEDI, W; CAPRIOLO, G; CARULLO, A; FUNARO, M. 2014. New strawberry cultivars tested in Spain and south Italy. Acta Horticulturae 1049: 471-474.

OLIVEIRA, RP; SCIVITTARO, WB. 2011. Desempenho produtivo de cultivares de morangueiro. Scientia Agraria 12: 69-74.

OTTO, RF; MORAKAMI, RK; REGHIN, MY; CAÍRES, EF. 2009. Cultivares de morango de dia neutro: produção em função de doses de nitrogênio durante o verão. Horticultura Brasileira 27: 99-110.

SANTOS, AM. 1999. Melhoramento genético do morangueiro. Informe Agropecuário Morango: tecnologia inovadora, Belo Horizonte, 20: 24-29. 